\title{
David Oliver: Nurse staffing levels are still not safe
}

\author{
David Oliver, consultant in geriatrics and acute general medicine
}

Berkshire

Setting out his vision to make the NHS "the safest in the world," Jeremy Hunt has discussed the need for a less bureaucratic, more people centred system using data. ${ }^{1}$ But endless bureaucratic flip-flopping and political meddling over safe nurse staffing levels illustrate the emptiness of his rhetoric.

In the final 2013 report of his public inquiry into Mid Staffordshire Hospital, ${ }^{2}$ Robert Francis specifically recommended that "minimum safe staffing and skill-mix levels should be drawn up by the National Institute for Clinical Excellence [NICE] and policed by the Care Quality Commission [CQC]." ${ }^{3}$

In 2013 the Department of Health evaded this. ${ }^{4}$ After pressure in professional publications, ${ }^{5}$ it reluctantly agreed to commission NICE, ${ }^{6}$ which works independently of government and issues statutory and credible guidelines.

Safe nurse staffing was a concern before Francis and beyond England. For instance, the Royal College of Nursing had produced evidence reviews and recommendations. ${ }^{78}$ The Safe Staffing Alliance has campaigned tirelessly. ${ }^{9}$ The Welsh Assembly has a safe staffing bill. ${ }^{10}$ NICE had a body of academic research to call on, and the University of Southampton reported a detailed systematic review. ${ }^{11}$ This analysed links between patient outcomes, care processes, nurse staffing, and skill mix in 35 primary studies, with clear associations demonstrated.

Then NHS England subverted NICE's traditional independence by effectively stopping its work, getting its chief nurse to defend the decision to her peers. ${ }^{12}$ This was driven by fear that a national "formula" might prove unaffordable and inflate costs, but this wasn't explicitly acknowledged.

Meanwhile, the CQC was on the case, criticising many hospitals for inadequate nurse to patient ratios. No need for an army of inspectors to tell it that nine in 10 establishments are short of their own target that was driven by post-Francis transparency and safety.

Now NHS England has belatedly acknowledged, only after invocation of the Freedom of Information Act, the true scale of the nursing workforce crisis that ministers previously played down. ${ }^{14} 15$
Another information request in 2015, integrity, and courage from NICE's non-executive directors, led to the Health Service Journal releasing the staffing guidelines for settings including emergency departments and mental health being drawn up before they were killed off.

Most recently, the chief nurse of the new oversight body, NHS Improvement, told local services to use local discretion over the safe staffing evidence after all-which is where this story started. ${ }^{16}{ }^{17}$ The chief nurse also pushed the highly contentious suggested metric of "care hours per patient day." 18 The same body has told hospitals to reduce head count and cap agency spending, ${ }^{19}$ which will hardly help nurse to patient ratios.

Confusing, isn't it. How's that vision working out, Mr Hunt?

Competing interests: See www.bmj.com/about-bmj/freelancecontributors/david-oliver.

Provenance and peer review: Commissioned; not externally peer reviewed.

1 Department of Health. Hunt J. Speech at the King's Fund: Making healthcare more human-centred and not system-centred. 16 Jul 2015. https://www.gov.uk/government/ speeches/making-healthcare-more-human-centred-and-not-system-centred.

2 Francis R. The Mid Staffordshire NHS Foundation Trust public inquiry. 6 Feb 2013. http: //webarchive.nationalarchives.gov.uk/20150407084003/http://www.midstaffspublicinquiry. $\mathrm{com} /$.

3 Ford S. Francis report: NICE should draw up safe staffing levels. Nurs Times 2013 Feb 6. www.nursingtimes.net/news/reviews-and-reports/francis-report/francis-report-niceshould-draw-up-safe-staffing-levels/5054655.fullarticle. (Login required.)

4 Department of Health. Patients first and foremost: the initial government response to the report of the Mid Staffordshire NHS Foundation Trust public inquiry. Mar 2013. https:// www.gov.uk/government/uploads/system/uploads/attachment_data/file/170701/Patients First_and_Foremost.pdf.

5 Lintern S. Nurse managers: DH is yet to refer vital safe staffing work to NICE. Nurs Times 2013 Aug19. www.nursingtimes.net/roles/nurse-managers/surprising-lack-of-progresson-nice-staffing-level-guidance/5062365 fullarticle. (Login required )

6 Department of Health. Hard truths: the journey to putting patients first. Jan 2014. https:/ www.gov.uk/government/uploads/system/uploads/attachment_data/file/270368/34658_ Cm_8777_Vol_1_accessible.pdf.

7 Royal College of Nursing. Safe staffing for older people's wards. 2012. https://www2.rcn. org.uk/_data/assets/pdf_file/0009/476379/004280.pdf.

8 Royal College of Nursing. Guidance on safe nurse staffing levels in the UK. 2010. https: //www2.rcn.org.uk/ data/assets/pdf file/0005/353237/003860.pdf.

Safe Staffing Alliance. www.safestaffing.org.uk.

10 National Assembly for Wales. Bill summary: the Safe Nurse Staffing Levels (Wales) Bill. Feb 2015. http://bit.ly/21WD5Eu.

11 Griffiths P, Ball J, Drennan J, Jones J, Recio-Saucedo A, Simon M. University of Southampton Centre for Innovation and Leadership in Health Sciences. NICE safe staffing for nursing in adult inpatient wards in acute hospitals: evidence review. 2014. http://eprints. soton.ac.uk/367526/ 
12 Cummings J, NHS England. Letter from chief nursing officer for England: ensuring the NHS is safely staffed. 11 Jun 2015. https://www.england.nhs.uk/wp-content/uploads/2015/ 06/cno-safe-staffing-letter-stakeholders.pdf.

13 BBC News. NHS nursing levels: nine in 10 hospitals missing targets. 21 Dec 2015. www. bbc.co.uk/news/health-35148920.

14 Campbell D. NHS has 70000 fewer staff, new figures reveal. Guardian 2016 Apr 3. www. theguardian.com/society/2016/apr/02/nhs-staffing-crisis-70000-go-missing.

15 Hughes D, Clarke V. Thousands of NHS nursing and doctor posts lie vacant. BBC News 2016 Feb 29. www.bbc.co.uk/news/health-35667939.

16 Lintern S. NICE releases safe staffing reviews to HSJ. Health Serv J 2016 Jan 18. www. hsj.co.uk/topics/workforce/nice-releases-safe-staffing-evidence-reviews-to-hsj/7001690. article. (Login required.)
17 Lintern S. NHS Improvement to allow local power over nurse staffing levels. Health Serv J 2016 Apr 21. www.hsj.co.uk/topics/workforce/nhs-improvement-to-allow-local-powerover-nurse-staffing-levels/7004110.article. (Login required.)

18 Dowler C. Carter review to back new measure of nurse productivity. Nurs Times 2016 Jan 22. www.nursingtimes.net/news/workforce/carter-review-to-back-new-measure-ofnurse-productivity/7001839.fullarticle. (Login required.)

19 Dowler C. Mackey: some trusts "not doing enough" to tackle agency spending. Health Serv J 2016 May 9. http://bit.ly/1WpfJYf. (Login required.)

Published by the BMJ Publishing Group Limited. For permission to use (where not already granted under a licence) please go to http://group.bmj.com/group/rights-licensing/ permissions 